\title{
Determinants of Sustainability Reporting of Islamic Banks in Emerging Countries
}

\author{
Afifah Oki Nilasakti', Falikhatun ${ }^{2}$ \\ ${ }^{1,2}$ Universitas Sebelas Maret, Indonesia.
}

Submitted: 10 August 2020; Accepted: 10 January 2021; Published: 14 January 2021

\begin{abstract}
This study aims to determine the effect of Islamic corporate governance and slack resources on sustainability reporting of Islamic Commercial Banks in Indonesia and Malaysia from 2015-2018. The corporate governance in this study consists of sharia supervisory board, the size, board of directors meeting, and audit committee. This is a quantitative study that used secondary data such as the annual and sustainability report. The reporting proxy was measured by the content analysis method which consisted of 78 items from the six dimensions adopted disclosure of AAOIFI. Furthermore, the analysis technique used was panel data regression with Random Effect Model (REM) as the estimation model. The results showed that the sharia supervisory board has a negative effect on sustainability reporting, while the board size, audit committee, and slack resources have a positive effect. Meanwhile, the board of directors' meeting has no effect on sustainability reporting. Therefore, the related government agencies such as Otoritas Jasa Keuangan (Financial Service Authority/FSA) and Bank Negara Malaysia are able to consider that the regulation related to the composition of sharia supervisory board for banking is in line with international ideal standards.
\end{abstract}

Keywords: Islamic corporate governance, sharia commercial bank, slack resources, sustainability reporting 


\section{INTRODUCTION}

According to The Global Islamic Finance Report, sharia banking assets grew to reach US $\$ 2,591$ trillion in 2018 driven by global Islamic financial practices that bring good impact to various regions and continents, both in Asia, the Middle East, Africa, Europe, America, and Australia. The Ministry of Finance stated that Indonesia as the largest Muslim population in the world, is considered to be a bit left behind in the development of Islamic economics, but it has been ignored by the rapid development of Islamic financial institutions, especially in the banking sector since the last decade (Kemenkeu, 2018).

Bank Muamalat, one of the sharia commercial banks in Indonesia noted that in 2018, its financial performance in the last few years was not good. This is due to the problematic financing ratio which is too large, hence it decreased investors and investing funds (detikfinance.com, 2018). Also, The Financial Services Authority of Indonesia as the supervisor stated that problem occurs at Bank Muamalat due to an error in carrying out business strategies, not because of the lack of capital. This issue is related to the company's transparency to stakeholders and the sustainability concept. Unlike in Indonesia, Islamic finance supports the growth of Islamic commercial banks in Malaysia, thereby providing a good performance record (www.ram.com.my, 2019). Also, the difference between condition is related to transparency towards stakeholders.

A global investor survey highlighted by Ernst \& Young stated that transparency is aimed at maintaining the entity's relationship with its stakeholders which is carried out by conducting social responsibility and disclosing it in the sustainability report (webforms.ey.com, 2015). In addition to aspects of sustainability, accountability, and transparency in implementing social responsibility, AAOIFI (2010) in the Governance Standard no.7 states that there are other aspects or requirements which needs to be qualified by financial institutions such as religiosity, economic, legal, ethical, and discretionary. Islamic banks, as a collector and distributor of funds, are essentially carrying out the principle of prioritizing the quality of life improvement (Haniffa $\&$ Cooke, 2002). Therefore, Islamic banks are required to conduct social responsibility in order not to be ignored by their operational activities. Meanwhile, the main purpose of disclosing social responsibility is as a means of banks in showing compliance with the sharia law (Baydoun \& Willett, 2000). According to the World Business Council for Sustainable Development, several benefits obtained by companies through sustainability reporting are: being able to transparently provide information to stakeholder; building company reputation; as a resource in managing economic, social, and environmental impacts, as well as building a long-term trust to stakeholder. 
KPMG survey result stated that the driving factor for companies to conduct sustainability reporting is government regulation, hence the role of corporate governance is needed for decision making (hrasiamedia.com, 2017). Businesses which are managed by good governance will be more likely to remain sustainable (Prasojo, 2015). According to the General Guidelines for Sharia Business Good Governance Chapter IV, Islamic banking operations are managed by corporate governance which consists of general meetings of shareholders, a board of commissioners and directors, and a sharia supervisory board. These bodies are involved in strategic activities including sustainability reporting (Adams, Hermalin, \& Weisbach, 2010).

The implementation of social responsibility and organizational sustainability reporting requires adequate resources (Xu, Yang, Quan, \& Lu, 2015). Besides corporate governance, there is slack resources which could be an important factor to create sustainability synergy (Foss \& Christensen, 2001). Furthermore, slack resources can be used by companies to adapt to internal and external changing conditions (Bourgeois, 1981). Sustainability reporting becomes a transparency medium for stakeholders to know whether all resources owned by the company are properly used and not deviated from the norm, therefore they do not have to worry about sustainability issue in the future (Branco \& Rodrigues, 2006).

Previous studies by Arora and Dharwadkar (2011); Bukair and Rahman, (2015) also Ika, Dwiwinarno, and Widagdo (2017), showed the sharia supervisory board and corporate governance have a positive effect on CSR disclosure. Also, an effective corporate governance encourages companies to carry out social activities and disclose sustainability reporting. In contrast, Pratama and Yulianto (2015); Khasanah and Yulianto (2015); Siswanti, Salim, Sukoharsono and Aisjah (2017) Bastina and Bernawati (2019) found that sharia governance represented by the supervisory board and other corporate governance components has no effect on CSR disclosure.

This study also takes the perspective of slack resources besides corporate governance to encourage the realization of non-financial performance and sustainability reporting. Previous studies by Arora and Dharwadkar (2011); Anggraeni and Djakman (2017); and Kim, Shin, Shin, and Park (2019) concluded that slack resource has a positive effect on disclosure of social responsibility and sustainability. Other studies by Darus, Mad, and Yusoff (2014) contrary showed that slack resource has no effect on CSR disclosure.

By the various results of previous studies, this study is conducted using sample of Islamic commercial bank in Indonesia and Malaysia. Hence, the concept of sustainability reporting is adjusted to sharia aspects. The difference between this study and previous ones is the use of the variable Islamic corporate governance which is represented by sharia supervisory board, size, meetings, and audit committee. Therefore, this study aims to examine the effect of 
Islamic corporate governance and slack resources on sustainability reporting of Islamic Commercial Banks in Indonesia and Malaysia.

The existence of an implicit and explicit contract towards stakeholders encourages the realization of Islamic corporate governance. The supervisory board as part of the bank has the responsibility to supervise activities based on sharia principles. Furthermore, sustainable corporate activity followed by a proper disclosure is a form of corporate responsibility implementation towards God, stakeholders, and the natural environment. Farook, Hassan and Lanis (2011); Bukair and Rahman (2015); El Hussein (2018); and Mukhibad (2018), studied the influence of the sharia supervisory board on the CSR disclosure. The results showed that the number of boards influences CSR disclosure because the monitoring carried out is more effective. Previous studies also showed that the greater the size of the sharia supervisory board, the wider the sustainability reporting.

$\mathrm{H}_{1}$ a: Sharia supervisory board has a positive effect on sustainability reporting.

Board size according to the National Governance Policy Committee (KNKG) consists of the board of directors responsible for carrying out tasks and decision-making on operations whose composition is adjusted to the company complexity. Akhtaruddin, Hossain, Hossain and Yao (2009) which examined the board size effect on voluntary disclosure levels showed that the board size has a positive effect. Shamil, Syaikh, Ho and Krishnan (2014); Mahmood, Kouser, Ali, Ahmad, and Salman (2018) and Hu and Loh (2018) examined the effect of board characteristics on sustainability reporting. The study concluded that board size has a positive effect on sustainability reporting. Also, previous studies showed that the greater the board size, the better the decision-making quality, hence sustainability reporting is more extensive. $\mathrm{H}_{1} \mathrm{~b}$ : Board size has a positive effect on sustainability reporting.

Board of directors meeting is a communication and coordination media regarding company activities. In this meeting, the board of directors make decisions under certain conditions. Suryono and Prastiwi (2011) stated that high frequency of board meetings was able to build relationships between directors through communication and coordination. The meeting can realize good corporate governance, hence it has a positive effect on the company in disclosing sustainability reporting. Hu and Loh (2018) and Latifah, Rosyid, Purwanti and Oktavendi (2019) stated that the number of meetings has a positive effect on sustainability reporting. The board of directors is responsible for ensuring compliance with laws and regulations, including conducting sustainability reporting. Meanwhile, previous studies showed that the higher the intensity of board meeting, the more the chance of discussing sustainability reporting. 
$\mathrm{H}_{1} \mathrm{c}$ : Board of directors meeting has a positive effect on sustainability reporting.

The role of audit committee in supervision encourages the effective implementation of corporate governance, one of which is the principle of transparency that requires companies to reveal their business activities to stakeholders. Previous research by Aniktia and Khafid (2015) and Latifah et al. (2019) concluded that there is an influence between the audit committee on the disclosure of sustainability reporting. In this case, the committee is responsible for ensuring the company morally and ethically carry out business activities. The results of previous studies showed that the greater the size of the audit committee, the better the company supervision, hence the sustainability reporting will be more extensive.

$\mathrm{H}_{1} \mathrm{~d}$ : Audit committee has a positive effect on sustainability reporting.

Companies need resources to operate and be continually sustainable. To achieve this, the company needs stakeholders as one of the supporting components. Sustainability reporting becomes one of the transparency media to stakeholders (Branco \& Rodrigues, 2006). The implementation of social responsibility and sustainability reporting make organization need adequate resources (Xu, Yang, Quan, \& Lu, 2015). Anggraini and Djakman (2017) and Kim et al. (2019) examined the effect of slack resources on non-financial disclosures, and the results showed that there is a significant positive effect of slack resources on non-financial disclosures. Also, the results of previous studies showed that the greater the slack resources which can encourage companies to carry out sustainable activities, the wider the sustainability reporting. $\mathrm{H}_{2}$ : Slack resources has a positive effect on sustainability reporting.

\section{METHOD}

The data analysis method in this study is the analysis of the regression panel using Eviews 10. The processing step begins with estimation models selection, which included common, fixed, and random effect models. The chosen estimation model was random effect model.

Sustainability reporting is measured using content analysis with scoring for each index. Meanwhile, the disclosure aspects covered six parts with a total of 78 items adopted from AAOIFI (2010) regulations developed by Darus, et al. (2014). The six disclosure parts include (1) Strategy; (2) Governance; (3) Products; (4) Community development and social goals; (5) Employees; (6) Environment. Also, the sharia supervisory board (SSB) is measured by the number of the boards. Furthermore, the board size (BSIZE) is measured by the number of directors owned by the entity. Board of Directors Meeting (BODM) is measured by the intensity or number of board meetings during one reporting period. Audit Committee (ACOMM) is measured by the number of meetings during one reporting period and slack resources is measured by the natural logarithm of cash and its equivalents. 


\section{RESULTS AND DISCUSSION}

Samples obtained by the purposive sampling method were 14 BUS in Indonesia and 7 BUS in Malaysia for the period of 2015-2018. Some banks need to be eliminated because they do not meet the criteria, hence the final sample used for this study was 81 observational data.

Tabel 1. Descriptive Statistics

\begin{tabular}{lccccc}
\hline & N & Mean & Maximum & Minimum & Std. Dev. \\
\hline Dependent & & & & & \\
\hline SR & 81 & 0,647 & 0,9 & 0,41 & 0,117 \\
\hline Independent & & & & & \\
\hline SSB & 81 & 3,444 & 9 & 2 & 1,795 \\
\hline BSIZE & 81 & 5,197 & 11 & 2 & 1,926 \\
\hline BODM & 81 & 23,925 & 48 & 3 & 14,557 \\
\hline ACOMM & 81 & 11,580 & 37 & 3 & 6,143 \\
\hline SLACK & 81 & 26,416 & 31,475 & 20,628 & 2,907 \\
\hline
\end{tabular}

Source: Data Processing Results (2020)

Tabel 1 shows the results of descriptive statistical tests. The average sustainability reporting of Sharia Commercial Banks in Indonesia and Malaysia for the 2015-2018 period was $64.7 \%$. These results showed that SR Sharia Commercial Banks have disclosure percentages above countries in Southeast Asia at 59.2\% (www.asean-csr-network.org, 2018). Also, the maximum SR value of $90 \%$ is owned by Bank Syariah Mandiri and Bank BNI Syariah in 2018, while the minimum value of $41 \%$ is owned by SR Maybank Syariah in 2016.

The sharia supervisory board showed the smallest value of 2 and 9, with an average of 3.444 and a standard deviation of 1.779. This means that Sharia Commercial Banks in Indonesia and Malaysia on average have met the minimum standards of the supervisory board members under AAOIFI - Governance Standards No. 1 which states that the minimum composition of sharia supervisory board consists of 3 people.

Board size showed an average value of 5.197 and a standard deviation of 1.779. Meanwhile, the largest number of board sizes was 11 and the smallest was 2. Some differences are too far, but there are no standards that set the minimum limit of board a company can own including banking. According to the Bank for International Settlement (www.bis.org, 2016), the boards of directors number is adjusted to the size and complexity of the bank.

Board of directors meeting with an average value of 23,925, means that the board of directors physical meeting generally ranges from 24 times. According to the Bank for International Settlement (www.bis.org, 2016), the meeting frequency is adjusted to the size, complexity, structure, and risk of the related bank. The maximum number of board meetings was 48 , with a minimum of 3 . 
The audit committee was measured by the number of meetings with an average value of 11,580, which means 12 average meetings are conducted by the audit committee. The maximum meeting intensity was 37 and the minimum was 3. Furthermore, the standard deviation of 6.143 was smaller than the average value, hence the data distribution was small. This means that there is no large gap in the size of the largest and smallest audit committee.

Slack resources are measured by the natural logarithms of cash and its equivalent accounts. The minimum value of slack resources was 20,628 and a maximum of 31,475 . The results also showed an average value of 26.416 slack and a standard deviation of 2.907.

Hypothesis tests in this study include the F statistical test, the coefficient of multiple determination test $\left(\mathrm{R}^{2}\right)$, and the statistical t-test. Previously, a classic assumption test that had been conducted consisted of normality, multicollinearity, heteroscedasticity, and autocorrelation test. The results showed that the data were normally distributed and free from multicollinearity and heteroscedasticity.

Tabel 2. Regression Test Results

\begin{tabular}{lcccc}
\hline Hypothesis & $\begin{array}{c}\text { Independent } \\
\text { Variable }\end{array}$ & $\begin{array}{c}\text { Dependent } \\
\text { Variable }\end{array}$ & Coefficient & Prob. \\
\hline H1a (+) & SSB & SR & $-0,080$ & 0,026 \\
\hline H1b (+) & BSIZE & SR & 0,101 & 0,005 \\
\hline H1c (+) & BODM & SR & 0,018 & 0,302 \\
\hline H1d (+) & ACOMM & SR & 0,047 & 0,023 \\
\hline H2 (+) & SLACK & SR & 0,489 & 0,000 \\
\hline R-Square & & & 0,351371 & \\
\hline Adjusted R-square & & & 0,308129 & \\
\hline F-Statistics & & & 8,125686 & \\
\hline Probability(F-statistic) & & & 0,000004 & \\
\hline
\end{tabular}

Sources: Data Processing Results (2020)

Table 2 shows the $\mathrm{F}$ statistics probability value of 0.000 at a significance level of $1 \%$, therefore it can be concluded that the independent variables simultaneously influence sustainability reporting. The adjusted $\mathrm{R}^{2}$ value was 0.308 , which means that the study model with independent variables consisting of sharia supervisory board, size, the directors meeting, audit committee, and slack resources can explain sustainability reporting by $30.8 \%$. The remaining $69.2 \%$ is explained by other variables.

The t-statistic probability value of the sharia supervisory board variable showed 0.026 with a coefficient value of -0.080 indicating a negative point. This means that the greater the number of sharia supervisory boards, the narrower the sustainability reporting conducted by 
Islamic banks, and the smaller the information delivered. These results are consistent with Sukmadilaga and Lestari (2017), which stated that the board has a negative effect on disclosures. These results showed the lack of attention given to Islamic banks, therefore it is necessary to optimize the role in increasing reporting disclosure. It is also in line with Khoirudin (2013) related to the lack of influence by the sharia supervisory board. This is possible because it is still focused on operational activities such as ensuring that contracts are carried out under sharia principles and review of financial statements. Meanwhile, Abdullah, Percy and Stewart (2013) stated that the number of sharia supervisory boards needs to be divided into several main functions and tasks in order for each member to focus on bank reporting responsibilities under sharia procedures. Therefore, the results are not consistent with previous studies by Farook, Hassan, and Lanis, (2011), Bukair and Rahman (2015), El Hussein (2018) and Mukhibad (2018).

The board size variable showed a statistical probability t-value of 0.005 with a coefficient value of 0.101 , therefore board size has a significant positive effect on sustainability reporting. Furthermore, the board size supports the diversity of expertise possessed by the board of directors. This can help directors make decisions from various sides including sustainability reporting. The results support previous study by Akhtaruddin, et al., (2009); Shamil et al. (2014); and Hu and Loh (2018). Also, the board of directors is a top-level body in the management mechanism, especially in making strategic policies that managers need to follow. Also, the bigger size of directors can increase collective experience and expertise, hence the need for disclosure fulfillment is high.

The t-test statistical value obtained by the board of directors meeting variable is 0.302 at a significance level of $5 \%$, therefore the board of directors meeting does not have a significant effect on sustainability reporting. These results support Hasanah, Syam, and Jati (2017) and Ju Ahmad, Rashid, and Gow (2017) that board of directors meeting does not affect the sustainability reporting disclosure. However, these results do not support the general belief that board meeting coordination is important for better reporting. According to Hasanah, Syam, and Jati (2017), the results of the board meeting only focused on the discussion of financial statements because sustainability reports were only applied compulsorily by several companies in Indonesia. Ju Ahmad, Rashid, and Gow (2017) stated that although the board of directors meeting is important for protecting the shareholders' interests, the meeting was not properly carried out, especially in Malaysia. This is because companies in the country are dominated by family ownership, therefore several strategic positions are occupied by the same people which cause conflicts and decisions made are less efficient. According to Menon and Williams (in Ju 
Ahmad, Rashid, \& Gow, 2017), companies need to consider the role of board of directors meeting because the number of meetings indicates that the results were less optimal, therefore considered inefficient. Further, Vafeas (also in Ju Ahmad, Rashid, \& Gow, 2017) adds that directors' meetings need to be more reactive than proactive. Therefore, the results of this study are not consistent with previous ones namely Suryono and Prastiwi (2010), Latifah et al. (2018), and Hu and Loh (2018).

The probability value of the audit committee influence on sustainability reporting showed 0.023 with a coefficient value of 0.047 indicating a positive direction. These results support Aniktia and Khafid (2015) that the audit committee as part of the corporate governance mechanism has a positive effect on the sustainability reporting disclosure. This is also in line with Latifah et al. (2019) which showed that the committee influences the disclosure of sustainability reporting. Furthermore, the audit committee is responsible for providing the needs of directors by providing advice and recommendations on the company's business continuity under relevant regulations, principles, and ethical standards (Al-Bhaidani, 2014). In addition, the increased intensity of audit committee meetings increases awareness and experience among members, hence the disclosure of non-financial information in sustainability reporting is wider (Buallay \& AlDhaen, 2018).

The $\mathrm{t}$-value probability of the slack resources variable showed 0.000 at $5 \%$ significance with a coefficient value of 0.489 which indicates a positive direction. These results support Anggraini and Djakman (2017); and Kim et al. (2019). Slack resources according to the definition of Burgeouis (1981) is an excess of actual and potential resources possessed to be used by organizations in adapting to internal and external pressures. As the concept of Hodgson (1998) that a company is a collection of various kinds of resources, the impulse of the company appears to be used as a form of responsibility. From an Islamic perspective, this is supported in QS alBaqarah (2): 29 that humans as leaders have been trusted in the management of resources. In addition, the existence of slack resources can be used by companies in implementing sustainability activities and determining policies, therefore sustainability reporting becomes wider.

\section{CONCLUSION}

This study concluded several things, firstly, the sharia supervisory board, the board size and meetings, audit committee, as well as slack resources affect sustainability reporting. Secondly, the results partially showed that out of the four components of Islamic Corporate Governance, the board size, and audit committee have a positive effect on sustainability reporting. Thirdly, the sharia supervisory board has a negative effect. Fourth, the board of directors' meeting does not affect sustainability reporting, while fifth, slack resource has a positive effect. 
This study has practical implications such as Otoritas Jasa Keuangan and Bank Negara Malaysia to consider the preparation and development of regulations related to board composition for sharia banking, which is in line with international ideal standards. In addition, the Islamic commercial bank as carrying the operational activities can encourage BOD activities through meeting in order to run effectively, especially on sustainability discussion.

Limitations that need to be considered in this study are the variables and proxies, which are still limited, hence they are unable to contribute to the model. This is indicated by the adjusted r-square value obtained only at $30.8 \%$, therefore it is recommended for further studies to multiply references regarding variables and measurements. Also, this study period is still relatively short, hence it could not represent the real situation of Islamic Commercial Banks in Indonesia and Malaysia. Therefore, further study is expected to extend the period by five to ten years.

\section{BIBLIOGRAPHY}

Abdullah, W. A. W., Percy, M., \& Stewart, J. (2013). Shari'ah Disclosures in Malaysian and Indonesian Islamic banks: The Shari'ah Governance System. Journal of Islamic Accounting and Business Research, 4(2), 100-131. https://doi.org/10.1108/JIABR-102012-0063.

Adams, R. B., Hermalin, B. E. \& Weisbach, M. S. (2010). The Role of Boards of Directors in Corporate Governance: A Conceptual Framework and Survey. Journal of Economic Literature, 48(1), 58-107.

Akhtaruddin, M., Hossain, M. A., Hossain, M. \& Yao. L. (2009). Corporate Governance and Voluntary Disclosure in Corporate Annual Reports of Malaysian Listed Firms. Journal of Applied Management Accounting Research, 7(1), 1-20.

Al-Baidhani, A. M. (2014). The Role of Audit Committee in Corporate Governance: Descriptive Study. International Journal of Research \& Methodology in Social Science, 2(2), 45-57.

Anggraeni, D. Y., \& Djakman, C. D. (2017). Slack Resources, Feminisme Dewan, dan Kualitas Pengungkapan Tanggung Jawab Sosial Perusahaan. Jurnal Akuntansi dan Keuangan Indonesia, 14(1), 94-118. https://doi.org/10.21002/jaki.2017.06.

Aniktia, R., \& Khafid, M. (2015). Pengaruh Mekaniseme Good Corporate Governance dan Kinerja Keuangan Terhadap Pengungkapan Sustainability Report. Accounting Analysis Journal, 4(3), 1-10. https://doi.org/10.15294/aaj.v4i3.8303.

Arora, P., \& Dharwadkar, R. (2011). Corporate Governance and Corporate Social Responsibility (CSR): The Moderating Roles of Attainment Discrepancy and Organization Slack. Corporate Governance: An International Review, 19(2), 136-152. 
https://doi.org/10.1111/j.1467-8683.2010.00843.x.

Baydoun, N., \& Willett, R. (2000). Islamic Corporate Reports. Abacus, 36(1), 71-90.https://doi. org/10.1111/1467-6281.00054.

Bastina, A. D., \& Bernawati, Y. (2019). Sharia Supervisory Board, Audit Committee, and Corporate Social Responsibility Disclosure. Jurnal Akuntansi, 23(3), 349. https://doi.org/10.24912/ja.v23i3.600.

Bourgeois, L. J., III. (1981). On the Measurement of Organizational Slack. The Academy of Management Review, 6(1), 29-39. https://doi.org/10.2307/257138.

Branco, M. C., \& Rodrigues. L. L. (2006). Corporate Social Responsibility and Resource-Based Perspective. Journal of Business Ethics, 69(2), 111-132. DOI: 10.1007/s10551-006 9071-z.

Buallay, A. M., \& AlDhaen, E. S. (2018). The Relationship between Audit Committee Characteristics. $17^{\text {th }}$ IFIP International Federation for Information Processing, 3 (11195), 492-503.https://doi.org/10.1007/978-3-030-02131-3_44.

Bukair, A. A., \& Rahman, A. A. (2015). The Effect of the Board of Directors' Characteristics on Corporate Social Responsibility Disclosure by Islamic Banks. Journal of Management Research, 7(2), 506. https://doi.org/10.5296/jmr.v7i2.6989.

Darus, F., Mad, S., \& Yusoff, H. (2014). The Importance of Ownership Monitoring and Firm Resources on Corporate Social Responsibility (CSR) of Financial Institutions. Procedia - Social and Behavioral Sciences, 145, 173-180.https://doi.org/10.1016/j.sbspro.2014. 06.024 .

El Hussein, N. H. A. (2018). The Sharia Supervisory Board: Does it Influence Corporate Social Responsibility Disclosure by Islamic Banks? A Review. Journal of Islamic Studies and Culture, 6(1), 121-132. https://doi.org/10.15640/jisc.v6n1a13.

Farook, S., Hassan, M. K., \& Lanis, R. (2011). Determinants of Corporate Social Responsibility Disclosure: The Case of Islamic Banks. Journal of Islamic Accounting and Business Research,2(2), 114-141.https://doi.org/10.1108/17590811111170539.

Foss, N. J., \& Christensen, J. F. (2001). A Market-Process Approach to Corporate Coherence. Managerial and Decision Economics, 22 (4/5), 213-26.

Haniffa, R. M., \& Cooke, T. E. (2002). Culture, Corporate Governance and Disclosure in Malaysian Corporations. Abacus, 38(3), 317-349. DOI: 10.1111/1467-6281.00112.

Hasanah, N., Syam, D., \& Jati, A. W. (2017). Pengaruh Corporate Governance terhadap Pengungkapan Sustainability Report pada Perusahaan di Indonesia. Jurnal Reviu Akuntansi dan Keuangan, 5(1). 711-720. DOI: https://doi.org/10.22219/jrak.v5i1.4992. 
Hodgson, G. M. (1998). The Approach of Institutional Economics. Journal of Economic Literature, 36(1), 166-192.

Hu, M., \& Loh, L. (2018). Board Governance and Sustainability Disclosure : A Cross-Sectional Study of Singapore-Listed Companies. Sustainability, 10(7). https://doi.org/10.3390/ su10072578.

Ika, S. R., Dwiwinarno, T., \& Widagdo, A. K. (2017). Corporate Social Responsibility and Corporate Governance in Indonesian Public Listed Companies. SHS Web of Conferences, 34 (40), 1-11. DOI: 10.1051/shsconf/20173413002.

Ju Ahmad, N. B., Rashid, A., \& Gow, J. (2017). Board Meeting Frequency and Corporate Social Responsibility (CSR) Reporting: Evidence from Malaysia. Corporate Board Role Duties and Composition, 13(1), 87-99. https://doi.org/10.22495/cbv13i1c1art3.

Khasanah, Z., \& Yulianto, A. (2015). Islamic Corporate Governance dan Pengungkapan Islamic Social Reporting Pada Bank Umum Syariah. Accounting Analysis Journal, 4(4), 1-10. https://doi.org/10.15294/aaj.v4i4.9108.

Khoirudin, A. (2013). Corporate Governance dan Pengungkapan Islamic Social Responsibility pada Perbankan Syariah di Indonesia. Accounting Analysis Journal, 2(2), 227-232. https://doi.org/10.15294/aaj.v2i2.2919.

Kim, S. I., Shin, H., Shin, H., \& Park, S. (2019). Organizational Slack, Corporate Social Responsibility, Sustainability, and Integrated Reporting: Evidence from Korea. Sustainability, 11(16), 1-17. https://doi.org/10.3390/su11164445.

Latifah, S. W., Rosyid, M. F., Purwanti, L., \& Oktavendi, T. W. (2019). Good Corporate Governance, Kinerja Keuangan dan Sustainability Report (BUMN yang listed di BEI). Jurnal Reviu Akuntansi dan Keuangan, 9(2), 200-213.https://doi.org/10.22219/jrak. v9i2.56.

Mahmood, Z., Kouser, R. Ali, W., Ahmad, Z., \& Salman, T. (2018). Does Corporate Governance Affect Sustainability Disclosure ? A Mixed Methods Study. Sustainability, 10(1), 1-20. https://doi.org/10.3390/su10010207.

Mukhibad, H. (2018). Peran Dewan Pengawas Syariah Dalam Pengungkapan Islamic Sosial Reporting. Jurnal Akuntansi Multiparadigma, 9(2), 299-311.https://doi.org/10.18202 /jamal.2018.04.9018.

Prasojo, P. (2015). Pengaruh Penerapan Good Corporate Governance terhadap Kinerja Keuangan Bank Syariah. Jurnal Dinamika Akuntansi dan Bisnis, 2(1), 59-69.

Pratama, A., \& Yulianto, A. (2015). Faktor Keuangan dan Corporate Governance Sebagai Penentu Pengungkapan Sustainability Report. Accounting Analysis Journal, 4(2), 1-10. https://doi.org/10.15294/aaj.v4i2.7863. 
Shamil, M. M., Shaikh, J. M., Ho, P, \& Krishnan, A. (2014). The Influence of Board Characteristics on Sustainability Reporting: Empirical Evidence from Sri Lanka Firms. Asian Review of Accounting, 22(2), 78-97. http://doi.org/10.1108/ARA-09-2013-0060.

Siswanti, I., Salim, U., Sukoharsono, E. G., \& Aisjah, S. (2017). The Impact of Islamic Corporate Governance, Islamic Intellectual Capital and Islamic Financial Performance on Sustainable Business Islamic Banks. International Journal of Economics and Financial Issues, 7(4), 316-323.

Sukmadilaga, C., \& Lestari, T. U. (2017). Factors That Affect Islamic Corporate Governance. Proceeding of $1^{\text {st }}$ International Conference on Islamic Economics, Business and Philanthropy. 112-117. DOI:10.5220/0007077801120117.

Suryono, H., \& Prastiwi, A. (2011). Pengaruh Karakteristik Perusahaan dan Corporate Governance (CG) Terhadap Praktik Pengungkapan Sustainability Report (SR) ( Studi Pada Perusahaan - Perusahaan yang Listed (Go-Public) di Bursa Efek Indonesia (BEI) Periode 2007 - 2009). Simposium Nasional Akuntansi XIV Aceh, 1-32.

Xu, E., Yang, H., Quan, J. M., \& Lu, Y. (2015). Organizational Slack and Corporate Social Performance: Empirical Evidence From China's Public Firms. Asia Pacific Journal of Management, 32(1). 181-198. https://doi.org/10.1007/s10490-014-9401-0.

\section{Websites:}

http://aaoifi.com

https://asean-csrnetwork.org

https://bis.org

https://finance.detik.com

https://hrasiamedia.com

https://kemenkeu.go.id

https://ram.com.my

https://webforms.ey.com 